\title{
The Effectiveness of Utilising Modern Artificial Intelligence Techniques and Initiatives to Combat COVID-19 in South Korea: A Narrative Review
}

\author{
Maad M. Mijwil ${ }^{1}$, Abdel-Hameed Al-Mistarehi ${ }^{2}$ and Karan Aggarwal ${ }^{3}$ \\ ${ }^{1}$ Computer Techniques Engineering Department, Baghdad College of Economic Sciences University \\ Baghdad, Iraq \\ Email: mr.maad.alnaimiy [AT] baghdadcollege.edu.iq \\ ${ }^{2}$ Public Health and Family Medicine Department, Faculty of Medicine, Jordan University of Science and Technology \\ Irbid, Jordan \\ Email: awalmistarehi18 [AT] med.just.edu.jo \\ ${ }^{3}$ Electronics and Communication Engineering Department, Maharishi Markandeshwar (Deemed to be University) \\ Mullana, Ambala, India \\ Email: karan.170987 [AT] gmail.com
}

\begin{abstract}
All nations are facing significant challenges and difficulties in the face of an intense pandemic that controls human life, and many things have changed in life, which led to the doubling of the global economy and the difficulty of life for many of the world's inhabitants. At present, the nations are seeking to control the spread of the epidemic in them, as every country uses plans to prevent this pandemic. This article presents South Korea's experience in employing modern artificial intelligence techniques in facing COVID-19. Besides, the use of artificial intelligence techniques and their great role in analysing images of people with COVID-19 disease are discussed, and how they are used to save many lives of the victims. The data obtained in this article is from a group of studies, social networking sites, and news on TV channels in the first period of 2020, which are collected and summarised in this article. This study summarises the role of South Korea in facing the pandemic through the application of artificial intelligence techniques to detect the disease, tracking the injured through GPS and how an intelligent quarantine is established, diagnosing and examining the damaged remotely, applying an electronic platform to publish information about how to avoid infection and the use of robots to assist diagnose disease and use drones for sterilisation purposes.
\end{abstract}

Keywords- Artificial Intelligence, COVID-19, Coronaviruses, Pandemic, South Korea, Medicine.

\section{INTRODUCTION}

Since ancient times, our planet has been suffering from the many pandemics and chronic diseases that afflict it, and which have claimed the lives of a large number of people and caused great crises that took a long time to overcome. When back to previous years, it is observed that the world witnessed a dangerous pandemic in the 14th century, which is the black plague (Black Death) that killed between 75 to 200 million people and is believed to have originated in or near China, then moved to Italy and then to the rest of Europe, and then to various nations [1][2]. In 1521, smallpox appeared and killed more than 56 million people [3], while cholera killed more than a million people around the world between 1817 and 1923 [4] [5]. In addition, do not forget the Spanish flu, which appeared in 1918 and lasted two years until a vaccine was discovered for it and has killed more than 45 million people [6] [7]. There are many pandemics that afflicted the world that we cannot cover in this article. The spread of the SARS virus has killed 774 people [8], while MERS has killed at least 828 people since 2012 [9] [10]. In 2019, specifically in December, a fast-spreading virus that infects the world with ease, and there is no barrier to prevent it, and it is a strain of a coronavirus called COVID-19 [11-13]. This epidemic has killed, to the end of this article writing in April 2.85M obtained from the World Health Organization.

While scanning a group of articles published on the Internet, it has been noticed that a very important article entitled "The Secrets History of the first Coronavirus" from Forbs written by Alex Knapp [14], this author explains that the first coronavirus discovered is known as 229E in the early 1960s. In 1967 another species appeared, known as OC43, discovered by Dr. Ken McIntosh and wrote an article in the Boston Children's Hospital archives as shown in Figure 1(a). Figure 1 (b) shows the NASAL DRIP by Dr. David Tyrrell during a research trial in 1966. In 2002, a virus known as SARS appeared from China, which is a contagious and sometimes fatal respiratory disease and has spread widely in the countries of Southeast Asia [15] [16]. There is still no effective vaccine for it, and the Carlo Urbani (Italian physician) is 
the first to discover this virus and died because of it. In 2012, another type appeared, called Middle East Respiratory Syndrome (MERS), and is discovered in Saudi Arabia [17] [18]. Figure 2 presents the difference between the coronavirus (SARS, MERS, and COVID-19) in terms of transmission, number of infections and deaths, and the country from which the virus appeared. We do not know when this pandemic, which has become a major part of our life, will end, and we do not want it to remain. We want to return to our normal lives that all inhabitants of this planet desire.

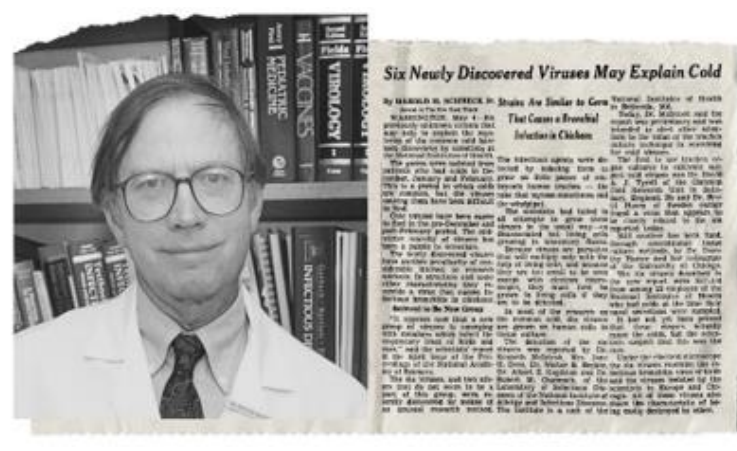

(a)

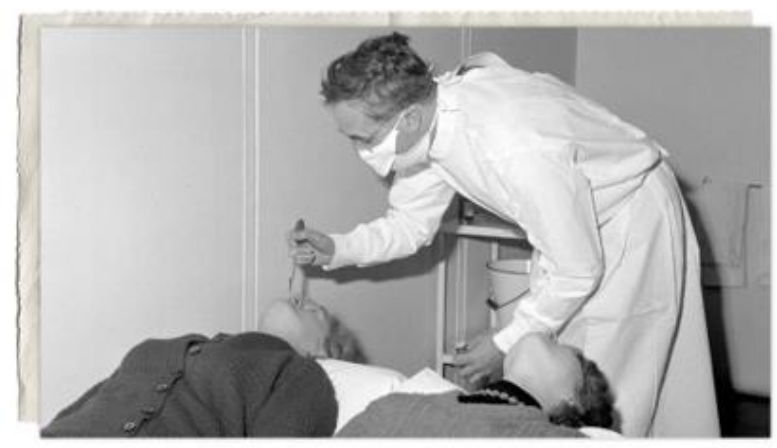

(b)

Figure 1: (a) Dr. Ken McIntosh of Harvard Medical School was part of the team that discovered OC43, an early coronavirus, in 1967. Boston Children Hospital Archives [14], (b) NASAL DRIP: Dr. David Tyrrell places a common cold virus into the nostril of a patient during a research trial in 1966 [14].

Since the emergence of COVID-19 [19] [20] in mid-December of 2019 and its outbreak in China and then in the rest of the world, this virus has caused several adverse effects and repercussions on various social, economic, political, cultural, sports and other fields, this has prompted the countries of the world to follow different methods and techniques to face the repercussions of this virus, including strict countrywide lockdown, nightly curfew, extensive contact tracing, quarantine and screening of asymptomatic contacts, and hospital isolation [21], which the World Health Organization considered a deadly and dangerous epidemic since March 2020 [22].

Among the modern methods and technologies that have been adopted are the artificial intelligence techniques that several countries have adopted in the face of this COVID-19 pandemic [23], the most famous of which is South Korea. If we look at social media, newspapers and articles, we will find many headlines and news praising the success of South Korea's experiment in using artificial intelligence in the face of the pandemic.

The main contribution of this article is a presentation of the practice of artificial intelligence techniques in medical fields and in the face of the COVID-19 virus, analysis of chest X-ray and CT scan images of the injured, and a presentation of South Korea's experience in facing the pandemic and how to use this science and reduce infections in it properly. The COVID-19 virus is the topic of the hour. There are many studies about this virus published recently, and this article is an academic reference on which researchers rely on future issues to explore COVID-19 in-depth.

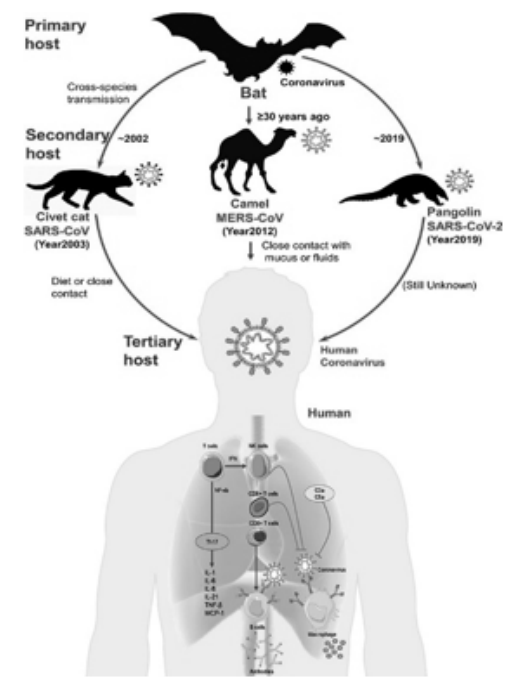

(a)

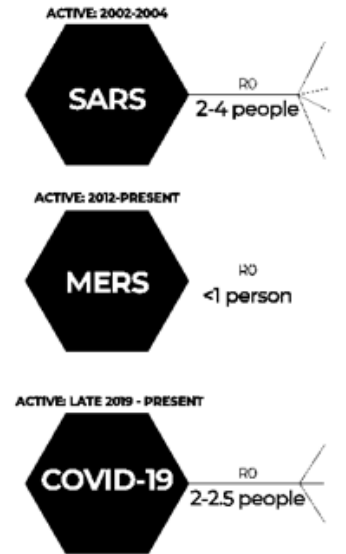

First reported Infections

(b)

Figure 2: (a) How to transmit Coronavirus (SARS, MERS, and COVID-19) diseases to the human lung [24], (b) Statistics of infections and deaths until April 18, 2020, from the Al-Jazeera website [25]. 
The rest of the article is organised as follows. The growth of intelligence techniques in the fields of medicine will be reviewed in Section 2. Then, in section 3, the story of the spread of COVID-19 in South Korea will be discussed. Section 4 discusses the mechanisms used by South Korea to address the pandemic. Finally, the conclusions reached in this article are presented in Section 5.

\section{ARTIFICIAL INTELLIGENCE IN THE MEDICINE}

Today, the science of artificial intelligence is growing significantly in the medical fields because it provides many facilities for monitoring patients remotely or thanks to diagnostic imaging of their condition [26] [27]. Actually, according to a 2016 report from CB Insights, $86 \%$ of organizations use AI in medical applications [28]. It is expected that by the year 2025, there will be advanced artificial intelligence systems that can respond quickly to specific questions for patients and facilitate the health management of the population through the use of digital images [29]. However, the current use is limited to the academic field. It is considered a support tool for healthcare employees that helps them accomplish and improve their work. In other words, this science is able, in a short time, to make great strides in the field of medicine, as some called it a physician in the future who would work to achieve what the medical staff could not make. Figure 3 is a set of images that show that shows the use of artificial intelligence in hospitals. All these images are downloaded from Google and converted to Grayscale colour.

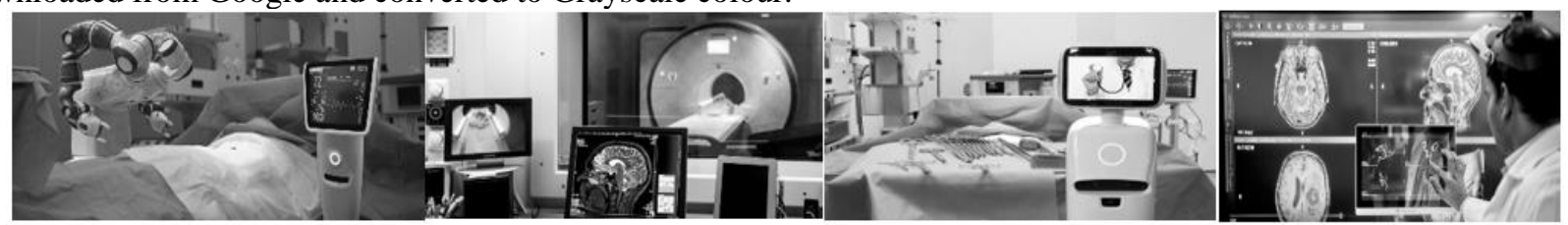

Figure 3: Artificial intelligence in hospitals

In 2018, the market share of artificial intelligence in the healthcare field reached about $\$ 2.1$ billion, and it is widely expected that the market share of artificial intelligence will reach more than $\$ 36$ billion by the year 2025 [30]. Through these words, we conclude that artificial intelligence has become vital in the medical field. The most influential factors that assisted in the growth of this science in the medical field are: The provision of big data in an unprecedented way, a large number of medical companies, the need for machines to do additional work alongside the medical staff, and the need for practical applications for patients. Here are some examples of the applications artificial intelligence has in medicine:

\section{Medical and Imaging Analysis [31-33]}

These applications aim to analyse and process a large set of data, especially when analysing medical tests such as magnetic resonance, brain cancer tumours and lung infections such as COVID-19. In fact, thanks to the increase in electronic records due to aggregation with sensors and wearables, there is a more significant amount of data available that can be processed and analysed thanks to artificial intelligence.

\section{Medical Diagnosis}

This is one of the most interesting applications, as it can make early and accurate diagnoses, especially for diseases that occur very quickly, such as breast cancer [34]. Through this application, the disease site is recognised early, treatment begins early, and progression in the body stops.

\section{Pharmacological Treatments [35]}

In pharmacology, artificial intelligence offers many improvements in serving researchers because it facilitates their work by analysing genetic sequences to discover vaccines or solutions suitable for different technologies. For example, artificial intelligence has assisted in discovering vaccines for COVID-19 [36], such as the Moderna, Pfizer, and Sinovac. Indirectly, it can be said that millions of lives have been saved by utilising artificial intelligence science.

\section{Genetics [37] [38]}

This field is very vital in human life because it contributes significantly to simply identifying diseases. Currently, there are tools that demonstrate this, such as a mobile application that allows, through the facial recognition system, to detect rare diseases and genetic disorders. A simple image of this technology is sufficient to treat a database of up to 8,000 different conditions.

\section{Pregnancies [39] [40]}

Thanks to the application of artificial intelligence in medicine, seeing the foetus and its stages of development is fantastic. In addition, this science enables a complete and detailed analysis of fatal data and immediately receiving large 
amounts of data on the state of pregnancy in real-time. This application allows you to enjoy a safer pregnancy and do without traditional surgical procedures.

\section{Prosthesis [41]}

Smart prostheses are limbs that are worn by certain (handicappers) people to adapt to them to accomplish their needs and movements. These are mechanical appendages that not only replace an organ of the body, but also maintain a person's movement patterns and can be controlled through an application.

The second part of this section discusses machine learning and its significant role in analysing X-ray images and chest CT images. In the beginning, everyone knows that machine learning is part of artificial intelligence; after the pandemic attacked the world, the urgent need for machine learning to have an influential role in the process of analysing the data of COVID-19 patients has become. This disease mainly attacks the human respiratory system; here, the physician's role may be weak in determining the percentage of disease in the lung or the type of disease because there are other diseases that affect the respiratory system similar to COVID-19 disease. So, the physician needs machine learning intervention to solve this problem. After several published studies, it is found that machine learning [42] has a large and essential role in discovering and classifying X-ray images and chest CT images of COVID-19 patients, as they can direct the physician's attention to areas with infection. For example, Figure 4 exhibits chest clip images of a 44-year-old Brazilian; after the analysis showed that the result is positive, meaning that he has COVID-19, and the results show that he has a fever and dry cough. More details about this study that is prepared in March 2020 in [43]. Figure 5 exhibits three positive X-rays, where A and B are images of a 14-year-old boy, and C is the image of a 10-year-old girl who is also infected [44]. Through all the words and figures mentioned, machine learning contributes to the success of the human lung examination process. Author M. M. Mijwil has written an article on how machine learning contributes to the rapid diagnosis of COVID-19 [45].

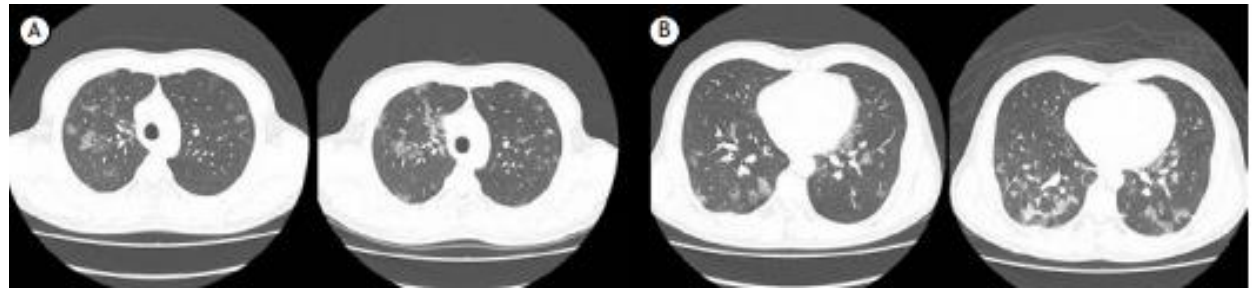

Figure 4: The stages of infection with COVID-19 disease for a person from Brazil, 44 years old

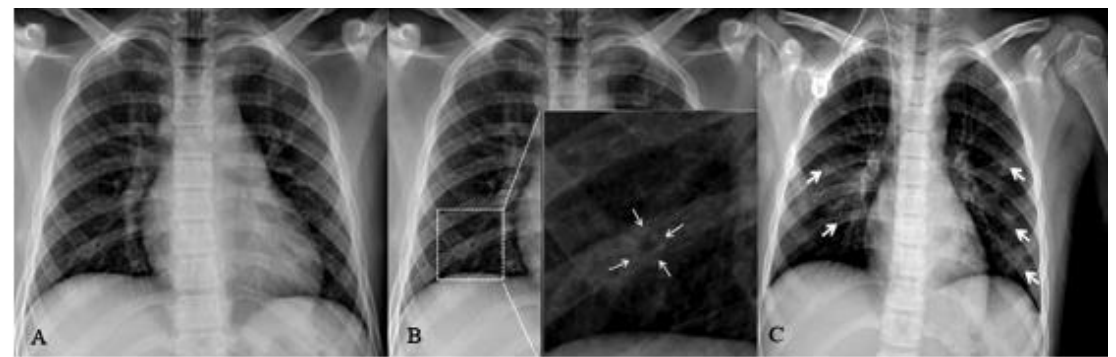

Figure 5: Three children with COVID-19

All of these examples are just a few samples of how artificial intelligence can enhance any area of medicine and health. It can interpret radiographs, facilitate the discovery of new drugs, and analyse the patient's genome. It also helps significantly improve the available healthcare resources, as those tasks that are often repeated can be automated.

\section{COVID-19 IN SOUTH KOREA}

In this section, the spread of COVID-19 in South Korea will be discussed. The first cases are announced in South Korea on February 19, 2020, in the first official announcement, the number of infected people is 20, for people returning from Wuhan, China. The story has appeared when Korea announced a new infection among its citizens, as 31 civilians are reported infected. The critical question is, how did the COVID-19 begin? The answer, according to what is reported in the newspapers, that a 61-year-old woman was called "Patient 31" by the Korea Disease Control and Prevention Agency (질병관리청). has, with a fever, participated on February 10 at the Shincheonji (신천지), Church of Jesus, the Temple of the Tabernacle of the Testimony in Daegu city, which is located in the southern part of the country and has a population of about 2.5 million and is $240 \mathrm{~km}$ from the capital Seoul. She does not stand here, but attended four church services before she is diagnosed with her infection with COVID-19. After that, it is founds that everyone who visited the churches had symptoms of COVID-19, and the number reached 9,000 civilians. Consequently, this older woman has infected $80 \%$ of cases in South Korea [46]. 
The number of infections in South Korea since the spread of the virus and up to the date of April 8, 2021 is 107,598, the number of those who have died is 1758 , and the number of those who have recovered is 98,360. Figure 6 is a set of images has been downloaded from Google showing the fogging operations and the transfer of infected people and civilian people wearing masks in the streets of South Korea. Figure 7 exhibits the number of infected in South Korea from the beginning of the outbreak until March 24, 2021.
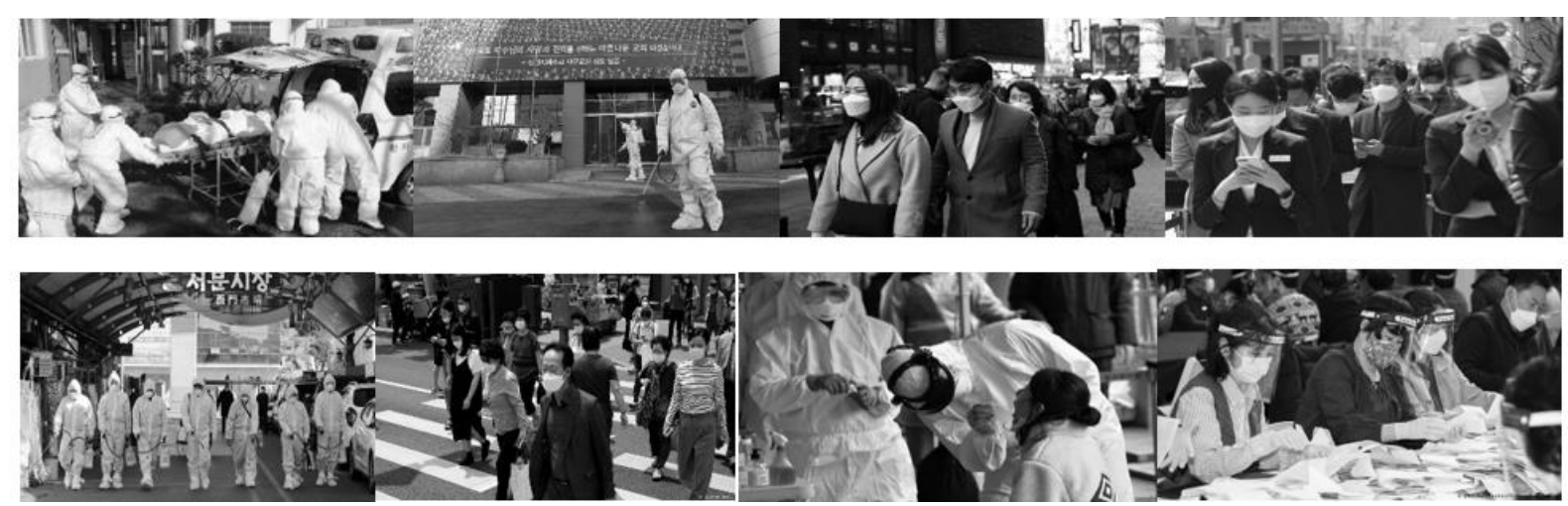

Figure 6: COVID-19 in South Korea.

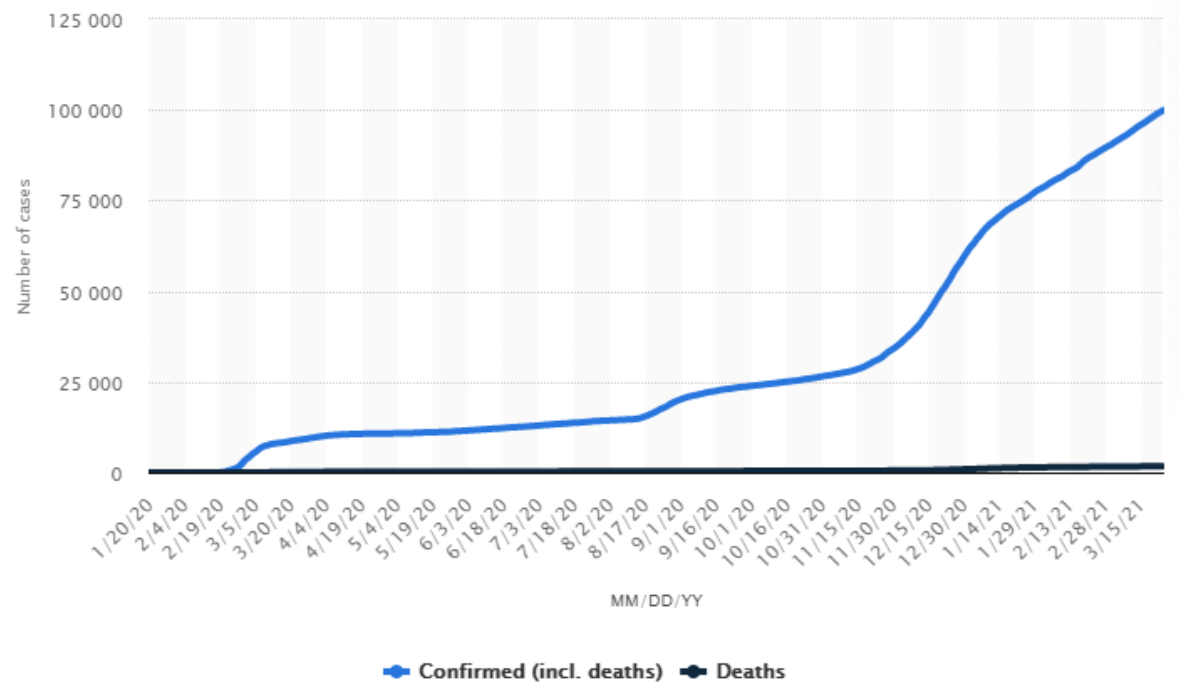

Figure 7: Number of COVID-19 confirmed and death cases in South Korea from January 20, 2020 to March 24, 2021 [47].

The numbers recorded in South Korea are perfect in comparison with the rest of the world. This indicates that this nation has great effectiveness in facing this pandemic, although it is one of the nations most affected in the early stages of the outbreak.

\section{SOUTH KOREA APPLIES AI TO COMBAT COVID-19}

After the pandemic spread dramatically worldwide, South Korea has taken several measures and practices that enabled it to control the virus and limit its spread. Among these measures and practices are: Its support for virus detection equipment manufacturers, which has led to an incredible speed in the development of infected detection devices more quickly, with the possibility of isolating them before infecting other people. South Korea has made a publicly available form containing information about the virus and made this form widely available publicly. It has built strict quarantine in all governorates of the nation. Forcing all health units in the Ministry of Health and Welfare and regional districts to confront COVID-19. The work of medical teams aimed at early detection of those showing symptoms of COVID-19. It has previous experience in facing MERS and SARS, which help it a lot in facing COVID-19. The intensive application of all modern technologies and E-devices to confront the pandemic spread in all its cities. The Korean citizens adhere to the measures adopted by their government with the rules of separation, cleanliness conditions, and wearing masks. Many masks in all pharmacies and supermarkets are provided and distributed, some of them free of charge to citizens.

South Korea has commenced using artificial intelligence techniques in the first period of the virus spread in it. Seegene has developed a rapid test to detect infected people using computing techniques and algorithms. This test is based on a group of chemical solutions that interact with samples taken from citizens with the help of robots that 
contribute greatly to the completion of the sampling process and mixing it with solutions to detect the presence of a virus in the citizen or not in a time of no more than four hours, which is a wonderful thing as this enables this nation is testing more than a million people in record time. Fortunately, South Korea has an intelligent quarantine information system. It has built in 2015 after the outbreak of the Middle East Syndrome (MERS) disease. Moreover, returning or departing travellers are forced to download an application on mobile to verify their self-health and know their cases during the estimated incubation period of 14 days. Also, there is another application for citizens, where this application works to warn users of cases of epidemic outbreaks at the places near them and allows them to inform the health centres nearby on them with their condition. The Korea Disease Control and Prevention Agency has developed an intelligent system that classifies cases of infection into four categories, which are weak, medium, strong and very strong, where each category is dealt with differently, giving special supplements and treatments, and also the method of isolation varies from one category to another. In addition, a global electronic platform for infectious diseases has been developed by the KT (Korean company), called the Global Epidemic Prevention Platform. This platform publishes health and accurate information about diseases. This platform is not only dedicated to Korea but rather works to expand its borders and it works in beta in Kenya and Ghana in this time. South Korea utilised big data technologies such as Global Positioning System (GPS) tracking data on telephones and vehicles, bank card transactions, travel records for arrivals and departures, and step-by-step tracking of infected individuals' paths. Also, monitoring the suspects, who are under home quarantine, to ensure that they do not leave the house or a penalty of up to $\$ 2,500$. Robots have been used to perform several auxiliary tasks such as measuring the temperature of the injured, distributing sterilisers, distributing masks, and other tasks. Drones have also been used to sterilise the most dangerous areas, such as hospitals and nearby regions. Table 1 exhibits the difference between Iraq and South Korea in terms of the total infections, deaths, and recovered among citizens until April 25, 2021, that is, before the spread of the Indiana COVID-19. These statistics are collected from the Worldometers website. This table shows the ability of artificial intelligence to confront this pandemic, as Iraq does not use the technologies employed by South Korea and thus increases the death rate among the infected and the spread of the disease will be more increased in all towns. Table 2 shows the confirmed cases and daily changes in each province until May 6 , 2021, and are more accurate in Figure 8. Table 3 surveys a set of studies that discussed South Korea's experience in facing COVID-19.

Table 1: The difference between Iraq and South Korea to combat COVID-19.

\begin{tabular}{ccccc}
\hline Nations & Population & Total Cases & Recovered & Deaths \\
\hline South Korea & $51,305,531$ & 120,673 & 110,248 & 1,821 \\
Iraq & $40,993,972$ & $1,045,010$ & 920,523 & 15,348 \\
\hline
\end{tabular}

Table 2: The confirmed cases in each province [48]

\begin{tabular}{|c|c|c|c|c|}
\hline \multirow{2}{*}{$\begin{array}{c}\text { City/Province } \\
\text { English/Korean }\end{array}$} & \multicolumn{3}{|c|}{ Daily Change } & \multirow{2}{*}{ Confirmed Cases } \\
\hline & Daily Change & Local outbreak & Imported cases & \\
\hline Seoul (서울) & 212 & 211 & 1 & 38,975 \\
\hline Busan (부산시) & 28 & 28 & 0 & 5194 \\
\hline Daegu (대구시) & 7 & 7 & 0 & 9408 \\
\hline Incheon (인천시) & 19 & 19 & 0 & 5758 \\
\hline Gwangju (광주시) & 8 & 8 & 0 & 2453 \\
\hline Daejeon (대전시) & 18 & 18 & 0 & 1806 \\
\hline Ulsan (울산시) & 38 & 38 & 0 & 2093 \\
\hline Sejong (세종) & 1 & 1 & 0 & 373 \\
\hline Gyeonggi-do (경기도) & 142 & 142 & 0 & 35095 \\
\hline Gangwon-do (강원도) & 12 & 12 & 0 & 2784 \\
\hline $\begin{array}{c}\text { Chungcheongbuk-do } \\
\text { (충청북도) }\end{array}$ & 6 & 6 & 0 & 2677 \\
\hline $\begin{array}{c}\text { Chungcheongnam-do } \\
\text { (충청남도) }\end{array}$ & 15 & 13 & 2 & 3120 \\
\hline Jeollabuk-do (전라북도) & 5 & 5 & 0 & 1993 \\
\hline Jeollanam-do (전라남도) & 10 & 10 & 0 & 1111 \\
\hline Gyeongsangbuk-do & 22 & 21 & 1 & 4266 \\
\hline
\end{tabular}




\begin{tabular}{ccccc}
\hline $\begin{array}{c}\text { (경상북도) } \\
\text { Gyeongsangnam-do } \\
\text { (경상남도) }\end{array}$ & 17 & 17 & 0 & 4143 \\
Jeju (제주도) & 6 & 6 & 0 & 743 \\
$\quad \begin{array}{c}\text { Lazaretto } \\
\text { Total }\end{array}$ & 8 & 0 & 8 & 3527 \\
A black rectangle indicates that this province is the most confirmed case in it. & $\mathbf{1 2}$ & $\mathbf{1 2 5 5 1 9}$ \\
\hline
\end{tabular}

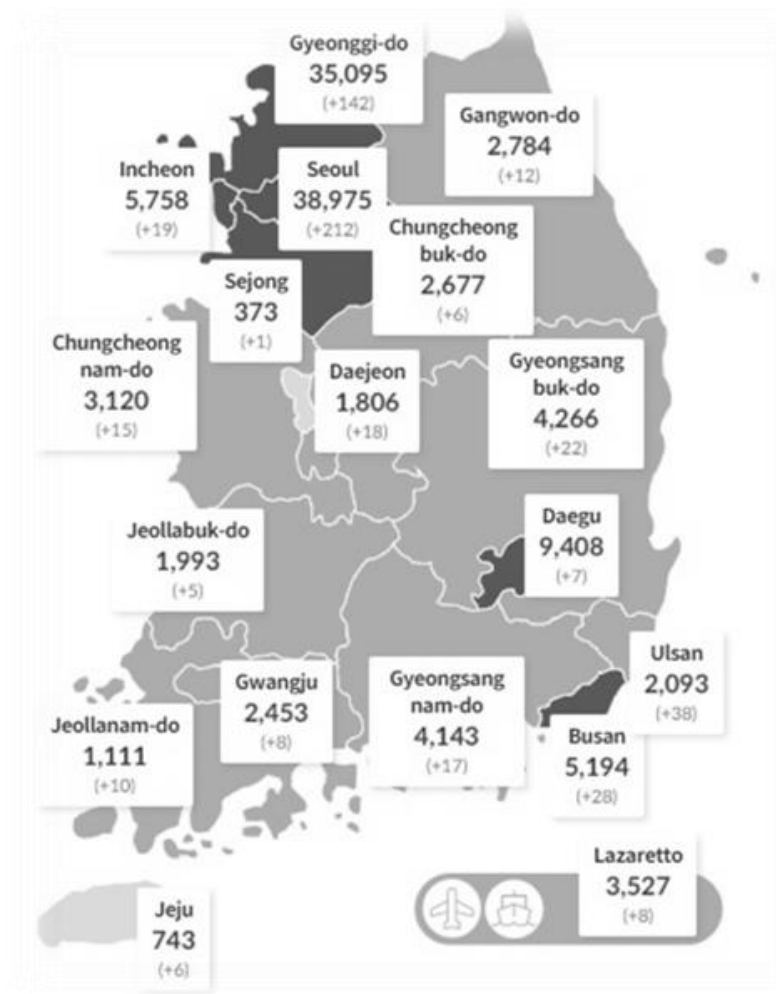

Figure 8: The confirmed cases in each province [48]

Table 3: Survey of a set of studies with the current study on South Korea in combating the COVID-19 pandemic

\begin{tabular}{cl}
\hline Literature & \multicolumn{1}{c}{ Description } \\
\hline Article [49] & $\begin{array}{l}\text { This study summarizes a review of the daily reports of the Korea centres for } \\
\text { disease control and prevention agency and collected information about the } \\
\text { procedures followed in hospitals. }\end{array}$ \\
\hline Article [50] & $\begin{array}{l}\text { This study gave a full description about South Korea's response to the outbreak of } \\
\text { the COVID-19 pandemic and how it was able to achieve achievements in reducing } \\
\text { the number of infections among its citizens. }\end{array}$ \\
\hline Article [52] & $\begin{array}{l}\text { Researchers have described the strategies that South Korea has put in place in } \\
\text { controlling the outbreak of the COVID-19 pandemic and the systems it has } \\
\text { designed to track cases of infection among citizens and also in hospitals. }\end{array}$ \\
\hline Article [52] & $\begin{array}{l}\text { This study is a comparison of health systems between South Korea and Italy and } \\
\text { how these systems work in the fight against COVID-19 }\end{array}$ \\
\hline Article [53] & $\begin{array}{l}\text { The author briefly explained about the outbreak of Covid-19 disease in South } \\
\text { Korea, as well as statistics of injuries in it, and comprehensively explained about } \\
\text { this pandemic. }\end{array}$ \\
\hline
\end{tabular}




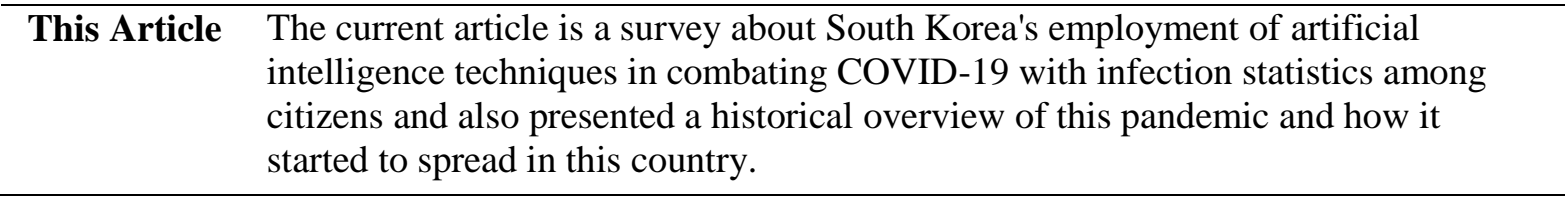

\section{CONCLUDING REMARKS}

In this article, the experience of South Korea in facing the COVID-19 pandemic is surveyed by employing artificial intelligence techniques to stop the spread of the pandemic by a large percentage, protect the lives of its citizens, reduce the number of injuries, and resume all economic, production, sports, cultural and entertainment activities in it. South Korea has proven that artificial intelligence is very necessary in its life and that it cannot be dispensed with, and proved that this science deserves every merit after its success in reducing injuries among its citizens, and this is a wonderful thing. The World Health Organization and several nations, such as the United States, Germany and the United Kingdom, also praised the success of the experiment. This article is a historical reference for the beginning of the truth of COVID19 and how one country in the world has succeeded in reducing the spread of the disease. Today, we live in the Indian COVID-19 period, which is the strongest among the disease strains and the deadliest. However, in the end, we believe that life will return to its normal state without fear of this virus.

\section{REFERENCES}

[1] Shipman P., "The Bright Side of the Black Death," American Scientist, vol.102, no.6, pp:410-413, December 2014. https://doi.org/10.1511/2014.111.410

[2] Ziegler M., "The Black Death and the Future of the Plague," The Medieval Globe, vol.1, no. 1, 2015, p. 259-283, 2015. Project MUSE. https://doi.org/10.17302/TMG.1-1.10

[3] Guharoy R., Panzik R., Noviasky J. A., Krenzelok E. P., and Blair D. C., "Smallpox: Clinical Features, Prevention, and Management," The Annals of Pharmacotherapy, vol.38, no.3, pp:440-447, March 2004. https://doi.org/10.1345/aph.1D272

[4] Awofeso N. and Aldabk K., "Cholera, Migration, and Global Health - A Critical Review," International Journal of Travel Medicine and Global Health, vol.6, no. 3, pp:92-99, September 2018. https://doi.org/10.15171/ijtmgh.2018.19

[5] Harris J. B., LaRocque R. C., Qadri F., Ryan E. T., and Calderwood S. B., "Cholera," Lancet, vol.379, no.9835, pp: 2466-2476, June 2012, https://doi.org/10.1016/S0140-6736(12)60436-X.

[6] Tsoucalas G., Kousoulis A., and Sgantzos M., "The 1918 Spanish Flu Pandemic, the Origins of the H1N1-virus Strain, a Glance in History," European Journal of Clinical and Biomedical Sciences, vol.2, no.4, pp:23-28, January 2016. https://doi.org/10.11648/j.ejcbs.20160204.11

[7] Erkoreka A., "Origins of the Spanish Influenza pandemic (1918-1920) and its relation to the First World War," Journal of Molecular and Genetic Medicine, vol.3, no.2, pp:190-194, December 2009.

[8] Stadler K., Masignani V., Eickmann M., Becker S., Abrignani S., Klenk H., and Rappuoli R., "SARS — Beginning To Understand A New Virus," Microbiology, vol.1, pp:209-218, December 2003. https://doi.org/0.1038/nrmicro775.

[9] Mackay I. M. and Arden K. E., "MERS coronavirus: Diagnostics, Epidemiology and Transmission," Virology Journal, vol.12, pp:1-21, 2015. https://doi.org/10.1186/s12985-015-0439-5

[10] de Groot R. J., Baker S. C., Baric R. S., Brown C. S., Drosten C., Enjuanes L., Fouchier R. A. M., Galiano M., Gorbalenya A. E., Memish Z. A., Perlman S., Poon L. L. M., Snijder E. J., Stephens G. M., Woo P. C. Y., Zaki A. M., Zambon M., and Ziebuhr J., "Middle East Respiratory Syndrome Coronavirus (MERS-CoV): Announcement of the Coronavirus Study Group," Journal of Virology, vol.87, no.14, pp: 7790-7792, July 2013. https://doi.org/10.1128/JVI.01244-13.

[11] Gennaro F., Pizzol D., Marotta C., Antunes M., Racalbuto V., Veronese N., and Smith L., "Coronavirus Diseases (COVID-19) Current Status and Future Perspectives: A Narrative Review," International Journal of Environmental Research and Public Health, vol.17, no.2690, pp:1-11, April 2020. https://doi.org/10.3390/ijerph17082690

[12] Mijwil, M. M., "Implementation of Machine Learning Techniques for the Classification of Lung X-Ray Images Used to Detect COVID-19 in Humans," Iraqi Journal of Science, vol.62, no.6., pp: 2099-2109, 2 July 2021. https://doi.org/10.24996/ijs.2021.62.6.35.

[13] Mijwil, M. M., Alsaadi, A. S, and Aggarwal K., "Differences and Similarities Between Coronaviruses: A Comparative Review," Asian Journal of Pharmacy, Nursing and Medical Sciences, vol.9, no.4, pp:49-61. 10 September 2021. https://doi.org/10.24203/ajpnms.v9i4.6696

[14] Knapp A., "The Secret History of the first Coronavirus," Retrieved from Forbes, April 2020, Available link: https://www.forbes.com/sites/alexknapp/2020/04/11/the-secret-history-of-the-first-coronavirus $229 \mathrm{e} / \mathrm{sh}=468 \mathrm{da} 21871 \mathrm{~d} 6$

[15] Hui D.S.C., "An overview on Severe Acute Respiratory Syndrome (SARS)," Monaldi Archives for Chest Disease, vol.63, no.3, pp:149-157, September 2005. https://doi.org/10.4081/monaldi.2005.632. 
[16] Vijayanand P., Wilkins E., and Woodhead M., "Severe acute respiratory syndrome (SARS): A Review," Clinical Medicine, vol.4, no.2, April 2004.

[17] Amer H., Alqahtani A. S., Alaklobi F., Altayeb J., and Memish Z. A., "Healthcare worker exposure to Middle East respiratory syndrome coronavirus (MERS-CoV): Revision of screening strategies urgently needed," International Journal of Infectious Diseases, vol.71, pp:113-116, April 2018. https://doi.org/10.1016/j.ijid.2018.04.001

[18] Azhar E. I., Hui D. S. C., Memish Z. A., and Zumla A., "The Middle East Respiratory Syndrome (MERS)," Infectious disease clinics of North America, vol.33, no.4, pp:891-905, December 2019. https://doi.org/10.1016/j.idc.2019.08.001

[19] Shereen M. A., Khan S., Kazmi A., Bashir N., and Siddique R., "COVID-19 Infection: Emergence, Transmission, and Characteristics of Human Coronaviruses," Journal of Advanced Research, vol.24, pp: 91-98, March 2020. https://doi.org/10.1016/j.jare.2020.03.005

[20] Harapan H., Itoh N., Yufika A., Winardi W., Keam S., Te H., Megawati D., Hayati Z., Wagner A. L., Mudatsir M., “Coronavirus Disease 2019 (COVID-19): A Literature Review," Journal of Infection and Public Health, vol.13, no. 5, pp: 667-673, May 2020. https://doi.org/10.1016/j.jiph.2020.03.019

[21] Khassawneh A. H., Alrabadi N., Al-Mistarehi A. H., Obeidat N., and Kheirallah K. A., "The role of non-state actors in combating COVID-19 spread in Northern Jordan," Annals of Medicine and Surgery, vol.60, pp:484-486, November 2020. https://doi.org/10.1016/j.amsu.2020.11.005

[22] Samrah S. M., Al-Mistarehi A. W., Ibnian A. M., et al., "COVID-19 outbreak in Jordan: Epidemiological features, clinical characteristics, and laboratory findings," Annals of Medicine and Surgery, vol. 57, pp:103-108, September 2020. https://doi.org/10.1016/j.amsu.2020.07.020

[23] Mijwil, M. M. and Al-Zubaidi, E. A., "Medical Image Classification for Coronavirus Disease (COVID-19) Using Convolutional Neural Networks," Iraqi Journal of Science, vol.62, no.8, pp: 2740-2747, 31 August 2021. https://doi.org/10.24996/ijs.2021.62.8.27.

[24] Kirtipal N., Bharadwaj S., and Kang S. G., "From SARS to SARS-CoV-2, Insights on Structure, Pathogenicity and Immunity Aspects of Pandemic Human Coronaviruses," Infection, Genetics and Evolution, vol. 85, no.3, 104502, November 2020. https://doi.org/10.1016/j.meegid.2020.104502

[25] Uras U., "Coronavirus: Comparing COVID-19, SARS and MERS," Retrieved from Al Jazeera, April 2020, Available link: https://www.aljazeera.com/news/2020/4/8/coronavirus-comparing-covid-19-sars-and-mers

[26] Ahuja A. S., "The impact of Artificial Intelligence in Medicine on the Future Role of the Physician," Peer J, vol. 7: e7702, pp:1-19, October 2019. https://doi.org/10.7717/peerj.7702

[27]Zhang Y., Chen G., Du H., Yuan X., Kadoch M., and Cheriet M., "Real-Time Remote Health Monitoring System Driven by 5G MEC-IoT,” Electronics, vol.9, no.1753, pp:1-17, October 2020. https://doi.org/10.3390/electronics9111753

[28] Article "From Drug R\&D To Diagnostics: 90+ Artificial Intelligence Startups In Healthcare," Retrieved from CBINSIGHTS, September 2019, Available link: https://www.cbinsights.com/research/artificial-intelligence-startupshealthcare/

[29] Lee D., and Yoon S. N., “Application of Artificial Intelligence-Based Technologies in the Healthcare Industry: Opportunities and Challenges," International Journal of Environmental Research and Public Health, vol.18, no.271, pp:1-18, January 2021. https://doi.org/10.3390/ijerph18010271

[30] Report "Artificial Intelligence in Healthcare Market Worth $\$ 36.1$ Billion by 2025" Retrieved from Markets and Markets, December 2018, Available link: https://www.prnewswire.com/news-releases/artificial-intelligence-inhealthcare-market-worth-36-1-billion-by-2025-exclusive-report-by-marketsandmarkets-tm--891319719.html

[31] Guan H. and Liu M., "Domain Adaptation for Medical Image Analysis: A Survey," Arxiv, ID:2102.09508v, pp:1-15, February 2021.

[32] Bruijne M., "Machine Learning Approaches in Medical Image Analysis: from Detection to Diagnosis," Medical Image Analysis Journal, vol.33, pp:94-97, October 2016. https://doi.org/10.1016/j.media.2016.06.032

[33] Aggarwal K., Bhamrah M. S., and Ryait H. S., "Detection of cirrhosis through ultrasound imaging by intensity difference technique," Eurasip Journal on Image and Video Processing, vol. 1, pp.1-10, October 2019, https://doi.org/doi: 10.1186/s13640-019-0482-Z

[34] McDonald E. S., Clark A. S., Tchou J., Zhang P., and Freedman G. M., "Clinical Diagnosis and Management of Breast Cancer," The Journal of Nuclear Medicine, vol.57, no.2, pp:9S-16S, February 2016. https://doi.org/10.2967/jnumed.115.157834.

[35] Farach F. J., Pruitt L. D., Jun J. J., Jerud A. B., Zoellner L. A., and Roy-Byrne P. P., "Pharmacological Treatment of Anxiety Disorders: Current Treatments and Future Directions," Journal of Anxiety Disorders, vol.26, no.8, pp:833843, August 2012. https://doi.org/10.1016/j.janxdis.2012.07.009

[36] Mijwil, M. M. and Abttan, R. A., "Artificial Intelligence: A Survey on Evolution and Future Trends," Asian Journal of Applied Sciences, vo19, no.2, pp:87-92, April 2021. https://doi.org/10.24203/ajas.v9i2.6589

[37] Dias R. and Torkamani A., "Artificial Intelligence in Clinical and Genomic Diagnostics,” Genome Medicine, vol.11, no.70, pp:1-12, 2019. https://doi.org/10.1186/s13073-019-0689-8 
[38] Ahmed A. A., Donepudi P. K., and Asadullah A. B. M., "Artificial Intelligence in Clinical Genomics and Healthcare,” European Journal of Molecular \& Clinical Medicine, vol.7, no.11, pp:1194-1202, 2020.

[39] Oprescu A. M., Miró-Amarante G., García-Díaz L., Beltrán L. M., Rey V. E., and Romero-Ternero M., “Artificial Intelligence in Pregnancy: A Scoping Review," IEEE Access, vol.8, pp:181450-181484, October 2020. https://doi.org/10.1109/ACCESS.2020.3028333

[40] Feduniw S., Sys D., Kwiatkowski S., and Kajdy A., “Application of Artificial Intelligence in Screening for Adverse Perinatal Outcomes A Protocol for Systematic Review, Medicine, vol.99, no.50, pp:1-5, December 2020, https://doi.org/10.1097/MD.0000000000023681

[41] Alshamsi H., Jaffar S., and Li M., "Development of a Local Prosthetic Limb Using Artificial Intelligence," International Journal of Innovative Research in Computer and Communication Engineering, vol.4, no. 9, pp:1570815716, September 2016. https://doi.org/10.15680/IJIRCCE.2016. 0409002

[42] Nur-A-Alam, Ahsan M., Based M. A., Haider J., and Kowalski M., "COVID-19 Detection from Chest X-ray Images Using Feature Fusion and Deep Learning," Sensors, vol.21, no.1480, pp:1-26, February 2021. https://doi.org/10.3390/s21041480

[43] Chate R. C., Fonseca E. K. U. N., Passos R. B. D., Teles G. B. S., Shoji H., and Szarf G., "Presentation of Pulmonary Infection on CT in COVID-19: Initial Experience in Brazil," Jornal Brasileiro de Pneumologia, vol.46, no.2, pp:1-4, March 2020. http://dx.doi.org/10.36416/1806-3756/e20200121

[44] Serrano C. O., Alonso E., Andrés M., Buitrago N., Vigara A. P., Pajares M. P., López E. C., Moll G. G., Espin I. M., Barriocanal M. B., Calle M. C., Rey C. C., and Bret-Zurita M., "Pediatric chest X-ray in covid-19 infection, European Journal of Radiology, vol.131, pp:1-6, October 2020. https://doi.org/10.1016/j.ejrad.2020.109236

[45] Mijwil M. M., "Machine Learning Helps in Quickly Diagnosis Cases of "New Corona"," Retrieved from Medium, April 2021, Available link: https://maadmijwil.medium.com/machine-learning-helps-in-quickly-diagnosis-cases-ofnew-corona-9d083b3cac66

[46] Lanese N., 'Superspreader' in South Korea Infects Nearly 40 People with Coronavirus," Retrieved from Live Science, April 2020, Available link: https://www.livescience.com/coronavirus-superspreader-south-koreachurch.html

[47] Number of coronavirus (COVID-19) confirmed and death cases in South Korea from January 20, 2020 to March 24 2021 by Statista, Available link: https://www.statista.com/statistics/1098721/south-korea-coronavirus-confirmedand-death-number/

[48] The Statistical data from the Ministry of the Interior and Safety of South Korea site, http://ncov.mohw.go.kr/en/bdBoardList.do?brdId=16\&brdGubun=162

[49] Kang J., Jang Y. Y., Kim J., Han S., Lee K. R., Kim M., and Eom J. S., "South Korea's Responses to Stop the COVID-19 Pandemic," American Journal of Infection Control, vol.48, no.9, pp:1080-1086, September 2020. https://doi.org/10.1016/j.ajic.2020.06.003

[50] Jeong E., Hagose M., Jung H., Ki M., and Flahault A., "Understanding South Korea's Response to the COVID-19 Outbreak: A Real-Time Analysis," International Journal of Environmental Research and Public Health, vol.17, no. 9571, pp:1-18, December 2020. https://doi.org/10.3390/ijerph17249571

[51] Hur S. J., Kang J. H., Cho M. G., Lee S. y., and Kang H. J., "Current Strategies for the Control of COVID-19 in South Korea," Food and Life, vol.1, no.e1, pp:1-16, March 2020. https://doi.org/10.5851/f1.2020.e1

[52] Palaniappan A., Dave U., and Gosine B., "Comparing South Korea and Italy's healthcare systems and initiatives to combat COVID-19," Revista Panamericana de Salud Pública, vol.44, pp:1-5, April 2020. https://doi.org/10.26633/RPSP.2020.53

[53] Choi J. Y., "COVID-19 in South Korea," Postgraduate Medical Journal, vol.96, pp:399-402, May 2020, https://doi.org/10.1136/postgradmedj-2020-137738 